\title{
Enhancing the fisheries sector of African Great lakes: Value chain analysis of the Tanganyika Sardine (Limnothrissa miodon, Boulenger 1906) from Lake Kivu, Rwanda
}

\author{
A. Murera ${ }^{1 *}$, M. Verschuur ${ }^{2}$, and Donald R. Kugonza ${ }^{3}$ \\ ${ }^{1}$ Rwanda Agriculture and Animal Resources Development Board (RAB), P. O. Box 5016 Rwanda. \\ ${ }^{2}$ Agricultural Production Chain Management (APCM), Van Hall Larenstein University of Applied Sciences, Velp, \\ Netherlands, P. O. Box 9001, 6880 GB Velp, Netherlands. \\ ${ }^{3}$ Department of Agricultural Production, School of Agricultural Sciences, College of Agricultural and Environmental \\ Sciences, Makerere University, Kampala, Uganda.
}

Received 2 October, 2019; Accepted 15 February, 2021

\begin{abstract}
Lake Kivu is experiencing unprecedented decline in production of Tanganyika Sardine (Limnothrissa miodon). This study sought to characterise the value chain of this fish species so as to chart its sustainable utilisation. The study performed in 2015 found two chains; an informal chain that takes $\mathbf{3 0 \%}$ of the production and a formal chain that handles $70 \%$. The average catch of sardine was $30 \mathrm{~kg} / \mathrm{day}$ in the high production season and $<15 \mathrm{~kg} / \mathrm{day}$ in the low season. Two thirds of the fishers were not aware of the governing law. Fishing malpractices included fishing in prohibited sites, beach seining and fishing during moratorium period. Majority of fishers were not satisfied with the price offered in the market as costs involved in fishing was 701 Rwanda Francs/kg caught. This is despite the shift in time since the study was performed. Therefore, there is need for re-training of value chain actors, increasing lake surveillance, strengthening internal controls of the Fishers' Cooperatives and improving information sharing and communication among value chain actors.
\end{abstract}

Key words: Chain mapping, fisheries, Lake Kivu, stakeholder analysis, Tanganyika Sardine.

\section{INTRODUCTION}

Fish contributes almost one-fifth of animal protein, slightly less than $10 \%$ of all proteins and is food for over three billion inhabitants of developing countries (FAO, 2018a) and in Africa over 200 million people rely on fish for their proteins (Obiero et al., 2019), vitamins and micronutrients, hence cannot be underestimated (Hicks et al., 2019).
Capture fisheries and aquaculture are both critical to food and nutrition but while aquaculture has been growing faster than any other food-producing sector (Bennett et al., 2018), the role of capture fisheries will remain significant being that several aquatic food species have not been domesticated or the registered success is not

*Corresponding author. E-mail: aimable.murera@gmail.com. Tel: +250788779807.

Author(s) agree that this article remain permanently open access under the terms of the Creative Commons Attribution License 4.0 International License 
yet widespread. With prices and preferences for fish being almost fixed and synched with better incomes, the per capita fish consumption in East Africa is expected to rise to $5.49 \mathrm{~kg}$ in 2022 from $4.8 \mathrm{~kg}$ a decade ago (FAO, 2018a; Obiero et al., 2019). The broader picture on marine capture fisheries has been blurred by the rapid spread of COVID-19 pandemic with poignant early 2020 reports from Africa, Asia (Bennett et al., 2020), Europe (Giannakis et al., 2020) and the USA (Smith et al., 2020), but with lifting of lockdowns in late 2020 the state is quickly normalising (Kaewnuratchadasorn et al., 2020). In East Africa, where livelihood losses were recorded, COVID-19 pandemic containment measures boosted fish stocks and coincided with expansion of fish breeding and nursery areas (Aura et al., 2020). Elsewhere, largely positive environmental narratives of the global pandemic have also been made (Stokes et al., 2020). Other agricultural enterprises did not fare any better in the early and mid-2020 from the widespread pandemic induced lockdowns (Zhang et al., 2020; Khan et al., 2021). In case the pandemic does not relent sooner, input utilization and productivity will shift, downstream waste water users will be threatened (lyiola et al., 2020) and GDP losses would continue (Duan et al., 2020; Zhang et al., 2020).

Lake Kivu, the smallest of East Africa's Great Lakes is home to various fish species for example the recently introduced Lamprichthys tanganicanus whose capture numbers are rising since 2006 and some but Limnothrissa miodon dominates (Guillard et al., 2012). Lake Kivu has a small littoral zone (12\% of total area), and home to 29 endemic fish species belonging to the Cyprinadae, Claridae and Cichlidae families (Snoeks et al., 2012). Like other inland lakes, it gets eclipsed by higher profile interest in ocean concerns (Funge-Smith and Bennett, 2019) but its role in food security and livelihoods is undisputed. In 1959, a small fish species of the Clupeidae family, L. miodon, Lake Tanganyika Sardine, locally called Isambaza was introduced into Lake Kivu and its fishing began 15 years later. Clupeoids are important food fishes largely used to produce fish oil and fish meal, and in various dishes and recipes, giving a distinct flavour. Tanganyika Sardine (TS) has adapted very well in Lake Kivu and is the most important stock, though two other commercially exploited fish: Haplochromis and Nile Tilapia are also present. TS is a vital fish in three African great lakes, Tanganyika (where it is endemic) and in Kivu and Kariba (where it was introduced) (Muzana and Guillard, 2014). Genetic analyses show that Lake Tanganyika's sardines have dynamically evolved genomes (Junker et al., 2020). By end of 2015, fishing activities on Lake Kivu had concentrated almost exclusively on Sardine followed by Haplochromis species (locally called Indugu), Oreochromis niloticus (Nile tilapia) and L. tanganicanus (Rwanda rushya). Compared to other large lakes of the East African Great Lakes region, Lake Kivu is species poor in fish fauna (Kisekelwa et al., 2020). Fishing TS is executed using a Trimaran fishing unit made of three boats of $6-7 \mathrm{~m}$ long wooden plank hulls, 4-5 lamps, nine fishers, and a lift net or set nets $1,000-2,500 \mathrm{~m}$ long. As an after effect of COVID-19, in October 2020, a new lift net called Icyerekezo consisting of one boat, a 1,000$1,500 \mathrm{~m}$ long lift net, 30 torches (in place of the lamps), was introduced, the main impetus being cost reduction and adjustment to limited labour available (KFP, 2020).

Hydro-acoustic estimates of the biomass of $L$. miodon fish stock in Lake Kivu reported stable stocks (2279 MT/year) for the Rwanda part of Lake Kivu (Guillard et al., 2012). Cichlidae (bream), Cyprinidae (carp) and Perciformes (Nile Perch) catches have not changed significantly over the three decades; the Clupeidae such as Limnothrissa have increased substantially and currently represent almost $75 \%$ of total inland capture fisheries in continental Africa (FAO, 2020). Rwanda has been experiencing a decline in fish stock due to increased fishing pressure and growth in fishing malpractices (MINAGRI, 2011). Capture fisheries in Kivu and other lakes is facing serious problems of overfishing due to influx of new entrants from rural areas (Spliethoff and Murasira, 2013) hence increase in fishing malpractices (Nibeza, 2015). The Rwanda Fisheries Law (http://extwprlegs1.fao.org/docs/pdf/rwa95441.pdf) was enacted to establish organisation and management of aquaculture and fisheries in Rwanda and to repeal an old fisheries law 1937. The legislation covers permitted fishing practices, restrictions in fishing, fishing licenses, and protection of aquatic organisms, hygiene, and quality of aquaculture and fishery products. It provides for fishers working in cooperatives and enforces a two-month moratorium on fishing activities in Lake Kivu so as to give fish the opportunity to grow and multiply. Considering that environmental conditions in Lake Kivu are good for Tanganyika Sardine fisheries, yields from the lake would be expected to be high, however this was not the case at the time of study (mid-2015) because the fishing techniques are too aggressive. It was, therefore, hypothesized that economic pressures and lack of information on long term sustainable fishing may be the causative factors. The scope of this paper is to describe a study that quantitatively and qualitatively assessed Tanganyika Sardine value chain and the extent to which the recommended practices for Tanganyika Sardine fishing and fisheries management are adopted, and to shed light on the relationships between the various Tanganyika Sardine value chain actors in Lake Kivu, Rwanda. This assessment would inform the formulation of competitive strategies, and reveal sources of competitive advantage for the sector.

\section{MATERIALS AND METHODS}

\section{Description of study area}

Three out of five districts bordering Lake Kivu were selected, namely Karongi, Rutsiro and Nyamasheke (Figure 1), as these 


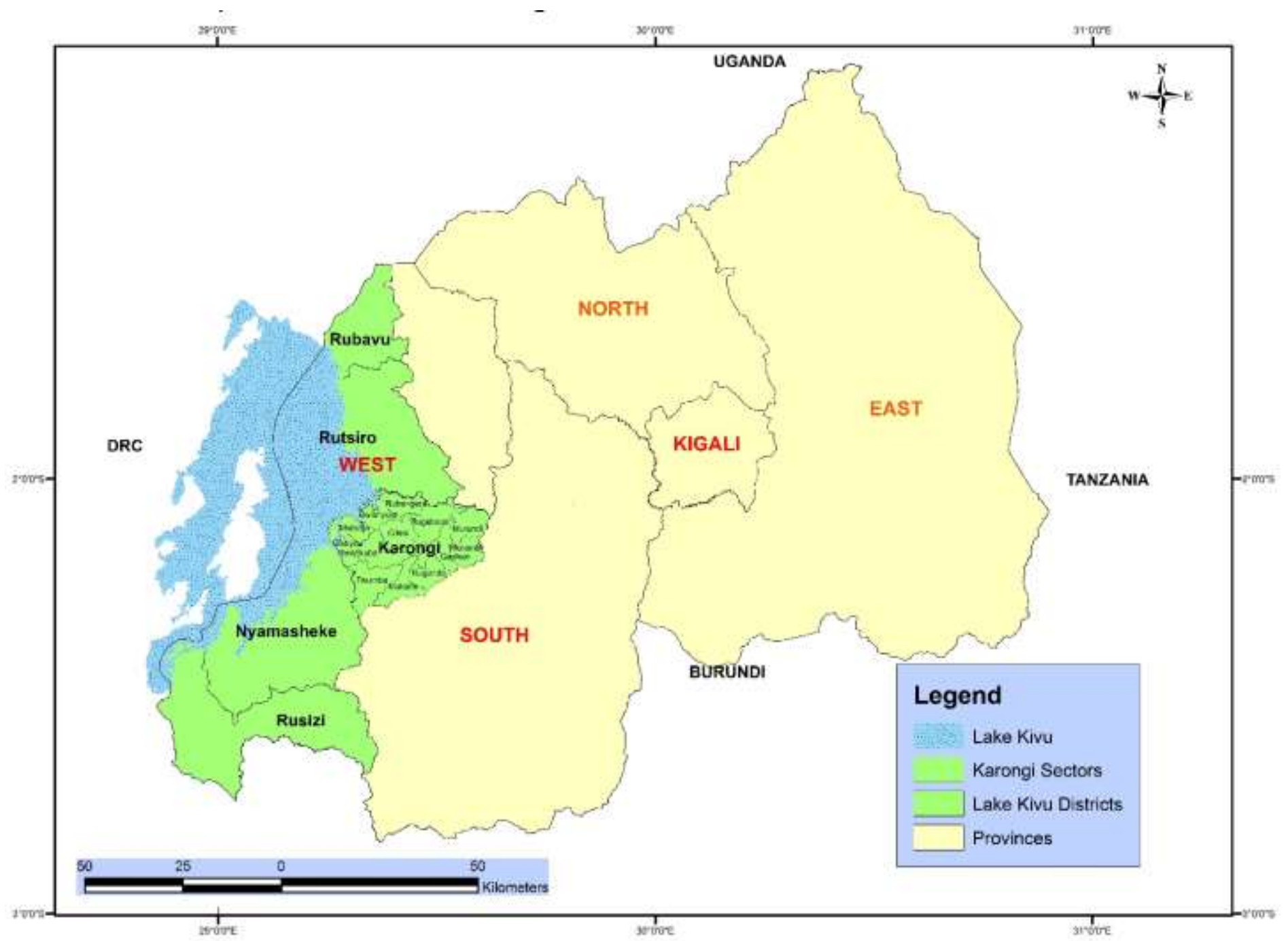

Figure 1. Map of Rwanda showing Karongi, Rutsiro and Nyamasheke districts in the Western province.

produce $>70 \%$ of Rwanda's annual Tanganyika Sardine catch and are among the fishing zones with most artisanal fishers. The average temperature of the area is $20^{\circ} \mathrm{C}$ (range: $16-21^{\circ} \mathrm{C}$ ). The high fish production period coincides with the October-May wet season while the low production period is from June to September. Annual rainfall range is $1,100-1,500 \mathrm{~mm}$ and means altitude range is 1,470 $2,200 \mathrm{~m}$ above mean sea level. The economy in the three districts is based on quasi-traditional agriculture, livestock farming and fishing that contribute about $33 \%$ of Rwanda's GDP (RURA, 2016). Fishers on Lake Kivu are grouped into six Fishing Cooperatives who sell their harvest to Kibuye Fishing Project (KFP) that transports, trades, and processes the fish and also supplies some inputs (fishing nets and fish transportation boxes).

\section{Sample size and sampling procedure}

The value chain study was conducted in mid-2015 using a survey and semi-structured interviews followed by focus group discussions. The period was selected to get the trend of activity in the fisheries calendar, to include the peak and trough. Purposively selected respondents were members of Fishing Cooperatives that make up a Fishing Union-a group of at least two Cooperatives whose business purposes are identical or complementary, and formed to represent and defend common interests. The Cooperatives were: Union des Coopératives des Pêcheurs et Vendeurs-Karongi (UCOPEVEKA), Union des Coopératives-Rutsiro (UCOPERUTSIRO) and Union des Cooperatives des Pêcheurs et Vendeurs-Nyamasheke (UCOOPEVEPNYA). The Union supplies fish to Kibuye Fishing Project (KFP) and in mid-2015 had a registered membership of 138 . Of these, 77 were Tanganyika Sardine fishers (and these made the sampling frame for this study), 38 were Haplochromis fishers, 10 were Nile Tilapia fishers, 2 were female owners of fishing units, the rest were non-active members (Table 1). The sample size, $\mathrm{n}$ of the respondent fishers was determined using Israel (1992) formula: $n=N /\left[1+N(e)^{2}\right]$; where: "N" is the population size (in this case 77), and "e" is the level of precision (in this case 10\%). A sample of 51 fishers was selected and interviewed from six Fishing Cooperatives. The sample size in Karongi was 27 fishers out of a total of 41 fishers (from 5 Cooperatives), the sample size in Nyamasheke was 11 fishers out of a total of 16 fishers (from 1 Cooperative), and the sample size in Rutsiro was 13 fishers out of a total of 20 fishers (from 2 Cooperatives). 
Table 1. Distribution of fishers of the various fish species among the Fishing Cooperatives in the study area.

\begin{tabular}{|c|c|c|c|c|c|c|c|c|}
\hline District & Sector & Cooperative & $\begin{array}{l}\text { Fishers } \\
\text { number }\end{array}$ & $\begin{array}{c}\text { Tanganyika } \\
\text { sardine } \\
\text { fishers }\end{array}$ & $\begin{array}{c}\text { Haplochromis } \\
\text { fishers }\end{array}$ & $\begin{array}{l}\text { Tilapia } \\
\text { fishers }\end{array}$ & $\begin{array}{c}\text { Female } \\
\text { owner of } \\
\text { fishing unit }\end{array}$ & $\begin{array}{c}\text { Non-active } \\
\text { members }\end{array}$ \\
\hline Karongi & \multirow{4}{*}{ Bwishyura } & Terimbere & 27 & 10 & 2 & 1 & 1 & 13 \\
\hline & & Twuzuzanye ku mwuga & 38 & 10 & 1 & 2 & 1 & 24 \\
\hline & & Baraka & 15 & 3 & 8 & - & - & 4 \\
\hline & & Nyakarwa & 14 & 2 & 9 & 3 & - & - \\
\hline & Gishyita & Ubumwe nyarwanda & 34 & 2 & - & - & - & 32 \\
\hline & Mubuga & Abizera & 20 & - & 2 & - & - & 18 \\
\hline Nyamasheke & Kirimbi, Mahembe and Gihombo & Cooperwa & 14 & 11 & 2 & - & - & - \\
\hline \multirow[t]{3}{*}{ Rutsiro } & Gihango & Coopegiku & 21 & 5 & 4 & 2 & - & 10 \\
\hline & Musasa & Coopejyamu & 18 & 8 & 10 & - & - & - \\
\hline & Total & & 201 & 51 & 38 & 8 & 2 & 102 \\
\hline
\end{tabular}

\section{Data collection methods}

Three different instruments namely, survey, semi-structured interviews and focus group discussions (FGD) were used for data collection. This was done to effectively and efficiently collect the various categories of data from the 51 respondents. For the survey, a questionnaire was used between April to September 2015 to gather data about the fishing practices used in Lake Kivu following the procedure of Bjorndal et al. (2010) for value chain analysis, deemed most suitable approach for this type of study. Data were collected on fishers' awareness of the law governing fishing in Rwanda, fishing practices, reasons of nonadoption of good fishing practices, ways to improve fishing practices, and challenges faced by fishers. Questionnaires were translated to Kinyarwanda language before conducting the survey, pre-testing was done with a select group of non-target respondents to ensure all questions were understandable to interviewees and was adjusted where needed. Interviews were done in the morning (0700$1100 \mathrm{~h}$ ) at the landing sites during the fishing period because in the period around full moon the fishers are usually on holiday.

Semi-structured interviews were used to collect data from other value chain actors and supporters. Seven key informant fishing actors were interviewed face to face using a checklist to gather relevant in-depth information (qualitative data) on the adoption of the legal measures in the capture of Sardines. The key informants were Fishing Cooperative Leader, President of the Fishing Union, Coordinator of Kibuye Fishing Project, District Veterinary Officers of Karongi, Rutsiro and Nyamasheke districts, Director of Livestock Extension in Rwanda Agriculture and Animal Resources Development Board (RAB) and Commander of Marine Rwanda National Police. Two FGDs were then conducted, with participants selected from the chain actors and supporters to complement the information gathered from the surveys. The first FGD consisted of six participatory appraisal tools (Stakeholder matrix, Value chain map, Value share analysis Venn diagram Historical diagram and problem priorities matrix).

\section{Data processing and analysis}

Data were checked, re-arranged, narrated and summarised; quantitative data were then coded, and entered into IBM SPSS Statistics Ver. 21. Data analysis involved generating means and frequencies. Value chain mapping was used to have a visual representation of the whole chain in the study districts with fish price at each actor's level. Value chain analysis to identify competitiveness was done using procedures of Webber and Labaste (2010). MS Visio software was used fo drawing the chain map, SWOT analysis was used to analyse the Strengths, Weaknesses, Opportunities and Threats of TS value chain, and MS Excel was used to compute value shares and cost benefit analysis.

\section{RESULTS}

\section{Value chain map for Limnothrissa miodon} (Tanganyika Sardine) for Rwanda

The chain map (Figure 2) shows the interactions between actors and supporters, and price of TS fish at different stages during the high production season (April-May).

The actors are: (a) fishing shop that supplies the fishing materials to the fishers; (b) the fishing unit that consists of nine fishers, one captain/team leader, three boats (one Trimaran); (c) Fishing Cooperative, an organisation of fishers to advocate for their interests; (d) Fishing Union that is responsible for collecting production from the fishers; (e) Kibuye Fishing Project (KFP), a private firm that collects fish from the Union, processes 


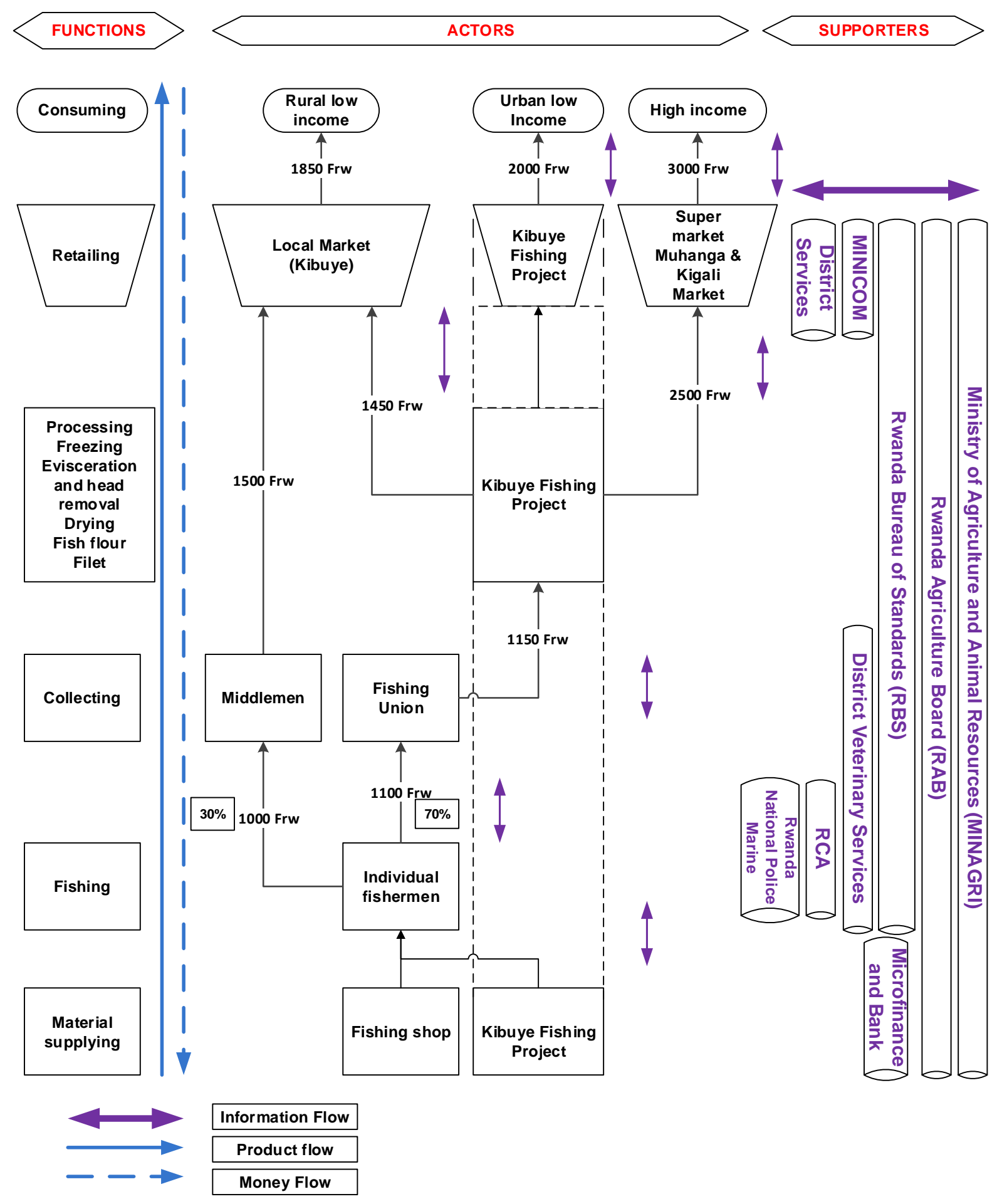

Figure 2. Tanganyika Sardine fish value chain map in Karongi, Rustiro and Nyamasheke districts, Rwanda (in April- May 2015).

it and trades it with consumers or other dealers. It also supplies fishing materials to fishers; f) fish retailers, who are exclusively women purchase fish from KFP and conduct business under any of three Cooperatives
(Huguka Benimpuhwe, $n=20$; Abakundisambaza, $n=13$; and Duharanirinyungu, $n=31$ ). g) Supermarkets located in Kigali City that buy fish from KFP and resell to the high income urban consumers. h) Consumers include 
institutional consumers such as hotels and restaurants, as well as urban medium income consumers who buy directly from KFP. Individual consumers buy either from supermarkets or the stall markets that are run by retailers (exclusively women), either in Karongi, Muhanga or Kigali city.

The supporters in the TS fish value chain are the following: (a) District Veterinary Officers-facilitate control and surveillance of fishing practices and capacity building of fishermen; (b) Rwanda Bureau of Standards (RBS)provides quality assurance and market surveillance/ monitoring of fish products retailed in the market to ensure that the fish is safe and fit for consumption (RBS, 2020); (c) Rwanda Agriculture and Animal Resources Development Board (RAB)-provides support in extension and research matters related to fisheries and provides policy and strategic advice on the core fisheries sector challenges; (d) Rwanda National Police-facilitates control and surveillance of fishing practices; (e)Microfinance and banks-provide loans to fishers and retailers; (f) Rwanda Cooperatives Agency (RCA)-promotion, registration and regulation of Cooperatives in the Rwanda, and g)Ministry of Trade and Industry-creates a business environment conducive to growth and protection of consumers.

\section{Socio-economic characteristics of the fishing households}

Fifty one fishers involved in the study originated from Karongi, Rutsiro and Nyamasheke districts (Table 1). Majority (53\%) came from Karongi, $25 \%$ from Rutsiro and $22 \%$ from Nyamasheke. The average age of the respondents was 39.7 \pm 1.1 years (range: 27-68 years). Moderate fishing experience was the norm, average number of years of fishing experience being $6.9 \pm 0.8$ years (range: $1-20$ years). Fishing was dominated by males (94\%) and only $6 \%$ of the respondents were female. Retailing of fish or products was by females exclusively (100\%). Knowledge is one of the important considerations in adoption of appropriate fishing practices. The majority $(82.4 \%)$ of interviewed fishers had primary education, only $5.9 \%$ had both primary and secondary education, and only $11.7 \%$ had never attended formal school.

\section{Status of Tanganyika Sardine fisheries, quantities caught and pricing}

The average sardine catch was $29.4 \pm 0.8 \mathrm{~kg} /$ day in the high production season (range: $20-35 \mathrm{~kg} /$ day) and $14.2 \pm 0.7 \mathrm{~kg} / \mathrm{day}$ in the low production season (Range: $10-20 \mathrm{~kg} /$ day). The mean selling price was $1,058.4 \pm 28.2$ Frw/kg (Range: $700-1,300 ; 1$ US $\$=700 \mathrm{Frw}$ ) in the high production season and 1,348.6 $\pm 24.8 \mathrm{Frw} / \mathrm{kg}$ (range: $1,100-1,700$ ) in the low production season. $79 \%$ of the respondents considered the price of fish to be insufficient both in the high and low production seasons. Three quarters of respondents agreed that the revenue is low compared to the costs involved in production; one third stated that the lower price on the market and instability of selling price $(11 \%)$ are key hindrances. On fish quality requirements, most fishers (85.3\%) ranked having hygiene materials for fish preservation as most important attribute desired, followed by supply of good fish (38.2\%), timely supply of fish $(38.2 \%)$; separation of fish catches into batches: first, second and third catch $(26.5 \%)$; other quality requirements contributed $5.9 \%$. These responses were not mutually exclusive and fishers chose more than one quality requirement they manage to attain. The most practiced aspect of fish quality assurance was maintaining fishing materials hygiene $(93.9 \%)$, use of motorised boat for timely fish transport $(27.3 \%)$, fishers' personal hygiene $(9.1 \%)$, conducting trainings on fish quality, using boxes for transporting fish (18.2\%). Regarding availability and pricing of fishing materials, to a high proportion of fishers $(76.4 \%)$, fishing materials were available and well-priced. The rest of the fishers gave a contrary opinion. Attempts to enforce a two months resting period moratorium started in 2014 but fishers did not respect it up to the time of the study. Recent efforts put in enforcing this resting period on Lake Kivu are starting to bear fruit.

\section{Awareness of the fishers on the law governing organisation and management of fishing in Rwanda}

Only $38.2 \%$ of all respondents knew about the Rwanda Fisheries Law. After explaining the contents of the law, all respondents agreed that there was limited enforcement of the law. Fishers mentioned several malpractices, namely: use of inappropriate nets $(94 \%)$, beach seining (94\%), fishing during the two-month moratorium "resting period" (91.2\%); fishing in fish breeding areas (88.2\%); fishing without holding a fishing license $(23.5 \%)$; parking Trimaran boats in forbidden landing areas, and fishing beyond the zone limited by the fishing license. Fishers who hold fishing licenses acknowledged deliberate breaching some rules on appropriate fishing practices. These included fishing in fish breeding areas $(43 \%)$, beach seining $(43 \%)$, fishing during moratorium $(27 \%)$. Malpractices by fishers who lack fishing licences were: use of inappropriate nets (97\%), use of child labour in fishing $(21 \%)$ and parking Trimaran boats in forbidden landing areas. Reasons for non-adoption of good fishing practices were: desire for bigger fish catches $(52.9 \%)$, hunger $(35.3 \%)$, high cost of fishing materials $(29.4 \%)$, decrease in overall production (14.7\%) as well as general impunity of the fishers (38.2\%). All fishers regularly sighted other fishers using bad fishing practices during their own fishing activity. Most fishers communicated to the police (85\%) and President of the Fishing Union 
(64\%); however, $15 \%$ of the fishers take no action.

\section{Challenges faced in adoption of good fishing practices and possible controls}

Fishers fail to adopt recommended practices due to easy access to inappropriate nets $(79.4 \%)$, high cost of approved fishing materials $(29.4 \%)$, insufficient training (17.6\%), impunity (8.8\%) and other issues (29.4\%), such as low fish prices, low fish catch, limited access to loans, and low involvement of local administration in the surveillance of Lake Kivu. Fishers suggested that to adopt good fishing practices destruction of inappropriate nets should be done first (85\%), then continuous training of fishers $(26.5 \%)$, training of local administrators (14.7\%), punishing of errant fishers (11.8\%), building linkages between actors and supporters in sardine fish value chain, ensuring the availability of ice, and ensuring availability of credit/loans.

\section{Value chain relations}

The Venn diagram (Figure 3) shows the power relationships between the different actors and stakeholders in the TS fishing sector. Kibuye Fishing Project has a strong relation with fishers, Fishing Cooperatives and Fishing Union. KFP has power in the chain because they buy from the Fishing Union all the fish produced and do participate in price fixing.

\section{Functions of the actors in the Tanganyika Sardine fish value chain}

The fishing shop supplies fishers with fishing inputs needed for TS capture such as nets, lamps and cables; and materials for transportation. The major challenges faced by fishing shops are: shortage of some materials that are imported, and fluctuations in prices of materials. Fishers own fishing units, do the fishing and sell the catches to the Union. The major risks faced by fishers are decreasing catches, fishing malpractices, limited capacity building, drowning of fishers, fluctuating fish prices, and high fishing material costs. Fishing Cooperatives are fishers organized into Cooperatives that offer various forms of support and protect members' interests. The major risks faced are limited funding, and a limited fishing area. The Fishing Union is responsible for collecting fish from fishers as Cooperatives are grouped under a Fishing Union. The major risks faced include a limited budget, limited capacity building of the fishers, decreases in harvests and increase in fishing malpractices. Kibuye Fishing Project is a private fish trading/processing company that buys fish from the Union and supplies fish transportation boxes; and the main risks faced are fluctuations in prices depending on fish availability and quality. Retailers are exclusively women, grouped into three Cooperatives and they buy fish from KFP and sell to consumers. Supermarkets in Kigali city and Muhanga buy fish from KFP and sell the products to the high income consumers in those locations. Consumers include institutional consumers such as hotels, restaurants; and urban consumers who buy directly from KFP. High income consumers buy either from supermarkets in Muhanga or Kigali.

\section{Analysis of the fishing costs and value shares of actors}

Computation of fishing costs (Table 3) was done considering the movement of fish in the value chain. Value share is essential for analysis of the economic contribution of different actors in the value chain and it also gives a clear idea about the profit margin between different actors. The fishers' price was $1,100 \mathrm{Frw} / \mathrm{kg}$ and the final consumer price was $1,850 \mathrm{Frw} / \mathrm{kg}$ for fresh TS in the formal TS fish value chain. The distribution of value shares was calculated from the Fishers, Fishing Cooperative and Union, KFP, and Retailers as 59, 5, 14 and $22 \%$ respectively.

\section{Historical diagram of the fish value chain and fishing practices}

The historical diagram to determine the perception of the fishers on TS fish population and fishing practices over the previous 20 years in the study area (Table 4) generally shows that the number of fishers had increased, price increased, and fishing malpractices increased but production decreased. However, after government intervention in the period following the survey, the situation has continuously improved.

The strength, weakness, opportunity and threat (SWOT) analysis matrix

Table 5 presents the strengths, weaknesses, opportunities and threats analysis of the Tanganyika Sardine value chain. These were aggregated for all the nodes of the value chain because they were cross-cutting more than one node/step of the TS value chain.

\section{DISCUSSION}

Tanganyika Sardine fish value chain, actors and their relationships

Considering that the prevailing COVID-19 situation will 


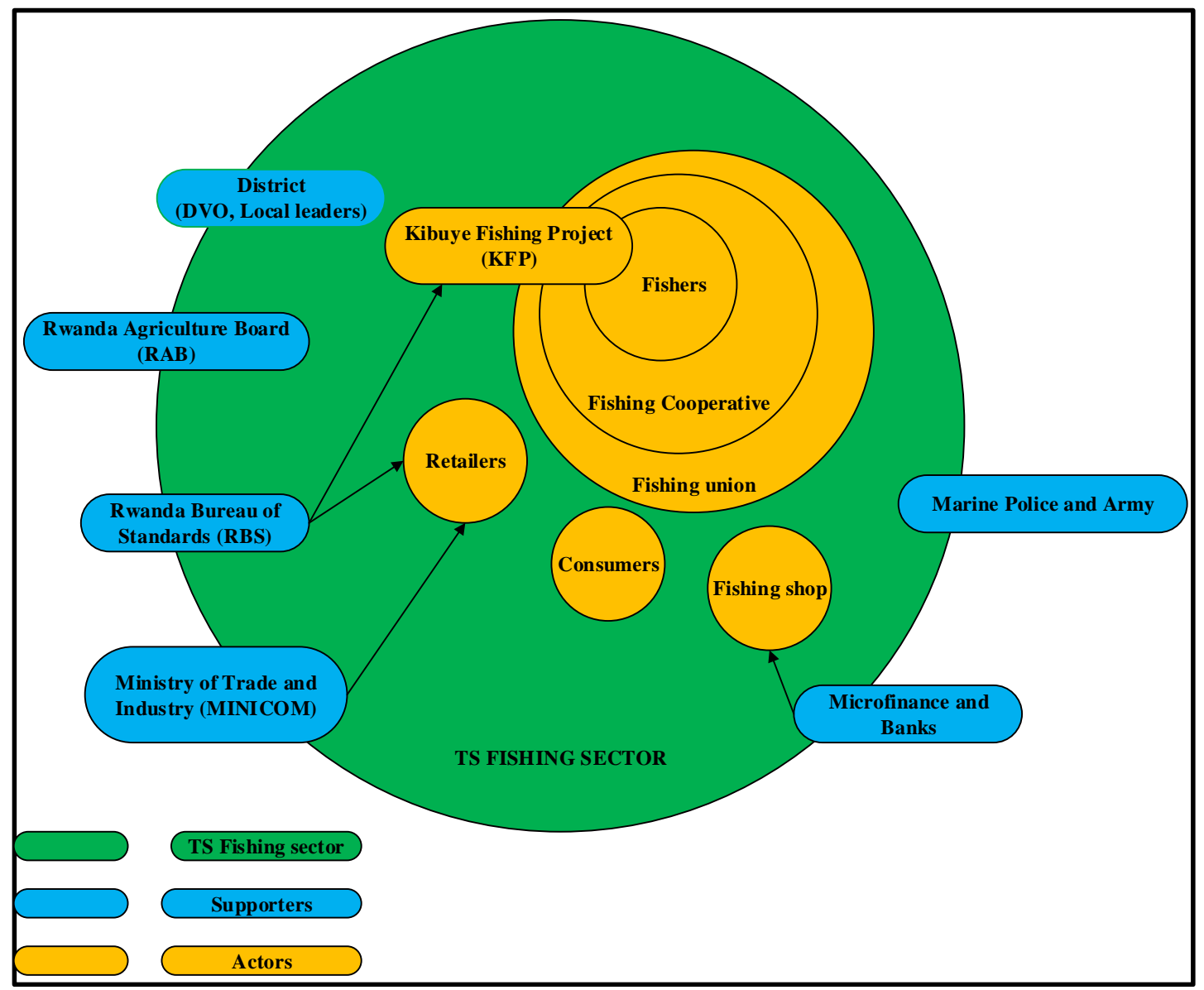

Figure 3. Venn diagram showing actors and supporters chain relation.

eventually normalise albeit not exactly to the previous state, demand for fisheries products from marine sources will get stretched by the hitherto growing need for nutritious and healthy food (Kolding et al., 2019). This study was conducted before COVID-19 pandemic rocked the world. A number of impacts on the fisheries and aquaculture sector have been noted and these need to be highlighted to relate to the situation in the fisheries world. During the first half of 2020, the main factors that swayed fishing and fish trade in Kenya and all of Africa, included dusk to dawn curfew as well as lockdown in major cities that are the major fish markets (Aura et al., 2020). These factors led to livelihood losses, reduced fishing times and trips and a significant reduction in availability of consumables causing meagre fish catches in Kenya (Aura et al., 2020), Southern Europe (Giannakis et al., 2020). Elsewhere, these impacts manifested in various forms including distrust of consumers on safety of products, shortage of raw materials for processing fish, barriers to trade in international markets, as well as general socio-economic instability (FAO, 2020; Kaewnuratchadasorn et al., 2020). Fisheries governance and sustainable utilisation will have to be addressed if the human population is to be sustainably fed. Predictions have shown that countries that depend on fish for protein requirements of their population, capture fisheries will remain the dominant supplier of that fish (Hall et al., 2013). The current study showed that fishing as a sector is vibrant, revealed by the presence of persons having several years of experience in the trade (Cowx and Ogutu-Owhayo, 2019). Age of the fishers shows that fishing activities were being performed mainly by the economically strong group aged $30-45$ years. Females were almost absent in capture activities because fishing is largely a nocturnal activity. As owners of fishing units, women are challenged in monitoring their employee fishers at the odd hours of night. Females are inadvertently perceived as not being confident or brave enough to participate appropriately in fish capture. The general disregard and under-valuation of women as a core actor in the fisheries sector especially at management and policy level has been documented (Harper et al., 2013) yet their direct economic contribution in several locations across the world is massive. Fishing communities do not usually value formal education, as has been reported elsewhere in Africa. Education enables 
communities to access information, interprets vulnerability for example, the HIV prevalence averages $20-30 \%$, and for women who depend on the fish value chain as the only source of livelihood, any negative impact on fisheries due to COVID-19 will ultimately make lack of access to education even worse (United Nations, 2020a).

Based on the results of the survey and FGDs, the quantity of Sardine caught was estimated to be $30 \mathrm{~kg} /$ day in the "high production season" (October-May, 2015) and thereafter dropping to $15 \mathrm{~kg} /$ day for the low season (June to September, 2015). Amounts of fish caught directly affect fish consumption, and directly affects nutritional adequacy (Hanazaki and Begossi, 2010), hence, Lake Kivu yield should be supported by other investments such as cage culture, aquaculture and diversification to production of other protein sources. Production level reveals the core value of Sardine fisheries and its edge over other sectors (Hall et al., 2013). Such amounts of fish caught would be rated as small scale operations (Teh and Teh, 2016) but they surely add to national levels (Teh and Pauly, 2018).

On the functions of different actors in the value chain and their relationships, six functions identified were: supplying materials, fishing, collecting, processing, retailing and consuming. Fishers that were organized under Fishing Cooperatives did use good fishing practices, the Union then collected the fish catches and delivered it to Kibuye Fishing Project which either sold the fish fresh or processed it and sold products. Division of labour in the chain makes a lot of meaning considering that the value chain exists when all stakeholders in the chain operate in the way to maximise the generation of value along the chain (Hall et al., 2013; United Nations, 2020b). Presence of the informal value chain was estimated to account for $30 \%$ of the Sardine produced, with only $70 \%$ making it through the mainstream channel. Informality is attributed to the fishers who lack operational licenses and/or those who engage in fishing malpractices. These acts have an effect on the price paid to fishers as there is competition between fish caught using good practices and the illegal sold at lower prices informally.

On the role of supporters, The TS fish value chain is supported by RAB, RBS, RCA, district governments, marine police, army, microfinance institutions, commercial banks and various central government ministries, particularly, the Ministry of Trade and Industry. This study presumes that lack of coordination in surveillance of fishing practices in Lake Kivu by the supporters is the cause of fishing malpractices and fishing with inappropriate nets and boats. Cooperation and coordination of stakeholder organisations are keys to success in developing the value chain. Similarly, the influencers in the value chain particularly RAB should refocus its roles of capacity building of the fishers, enforcement of the fisheries law, and also supporting the surveillance of the lakes by monitoring of fishing practices. Providing policy and strategic advice on the fisheries sector challenges and collaboration with other supporters in the value chain also needs to be strengthened. Therefore, surveillance should be organised in collaboration with actors and supporters and strong involvement of local governments. Indirectly, this can be supported by delivering the fishing licenses to the fishing cooperatives and empowering them to inspect the fishing activities on the lake, with integral support of the marine police.

\section{Compliance with fisheries regulations and management of the sector}

Illegal fishing and poaching are rampant but their catches never get included in official statistics (Funge-Smith and Bennett, 2019). The use of illegal nets and boats was found to be more profitable since comparatively, the cost of the illegal fishing was; one net costing 200,000 Frw, one boat and two fishers while the legal fishing practice requires a net that costs 1,500,000 Frw, three boats, nine fishers and other materials.

This may imply that poorer fishers are more likely to use illegal equipment and methods so as to boost their income. Poverty was empirically found to have an important influence on exploitation of East African marine resources (Cinner, 2009). The profit margin of fresh Sardine sold is a paltry $399 \mathrm{Frw}$ (US\$0.44 per kg), a low reward for their efforts making the use of illegal means to boost daily catches tempting. During the study, and holding true in 2020 , Sardine prices were determined by a committee of seven, representing: Fishers' Cooperatives, Fish Retailers Cooperative, Fishing Union; and the Coordinator of Kibuye Fishing Project. While the price determination mechanisms seem elaborate and inclusive, fishers' voices matters and they have to own up collective decisions by their leadership. Institutional sustainability is needed to harmonise legal protocols for all of Lake Kivu, so that it is managed by both Congo D.R. and Rwanda. This has been achieved for regional lakes such as Lake Victoria for which the Lake Victoria Fisheries Organisation (https://lvfo.org/) was created. Lake fisheries are best managed for entire lakes instead of each country doing their segment. Participatory approaches should be used to make fishers aware of the fishing malpractices and their negative impact on sustainable fishing business.

A low level of awareness of the fisheries law calls on $R A B$, district leadership and the Fishing Union to work hand in hand to raise awareness among fishers and local authorities and these efforts are being upped in 2020 in light of COVID-19 pandemic (Mugisha, 2020). The law highlights good fishing practices and should be supported through capacity building emphasizing that fish stocks in public waters are a common good till after harvest (Belton et al., 2014). A training of 150 people from the three studied districts on the law was done mostly for 
Table 2. The fishing costs per kilogram of Tanganyika Sardine fish caught.

\begin{tabular}{|c|c|c|c|c|c|}
\hline $\begin{array}{l}\text { Type of } \\
\text { revenue/cost }\end{array}$ & Level & Amount (Frw) & Annual (Frw) & $\begin{array}{c}\text { Monthly } \\
\text { (Frw) }\end{array}$ & $\begin{array}{c}\text { Day } \\
\text { (Frw) }\end{array}$ \\
\hline \multirow{2}{*}{ Production } & High production fishing period & $30 \mathrm{~kg} \times 24$ days $\times 8$ months $\times 1150$ Frw $=6624000$ & \multirow{2}{*}{$8,568,000$} & \multirow{2}{*}{71,400} & \multirow{2}{*}{29,750} \\
\hline & Low Production Fishing Period & $15 \mathrm{~kg} \times 24$ days $\times 4$ months $\times 1350$ Frw $=1944000$ & & & \\
\hline \multirow[t]{7}{*}{ Variable } & Food for fishers & 2500 Frw $\times 24$ days $\times 12$ months $=720,000$ & 720,000 & 60,000 & 2,500 \\
\hline & Kerosene & 800 Frw $\times 3$ liters $\times 24$ days $\times 12$ months $=768000$ & 69,200 & 57,600 & 2,400 \\
\hline & Kivu Fish Guard fee & 5000 Frw $\times 12$ months $=60000$ & 60,000 & 5,000 & 208 \\
\hline & Fish transport & 1000 Frw $\times 24$ days $\times 12$ months $=24000$ & 288,000 & 24,000 & 1,000 \\
\hline & Taxes & & 45,000 & 3,750 & 156 \\
\hline & Buying Other materials & & 150,000 & 12,500 & 521 \\
\hline & Contribution to the Cooperative Union + Sanitation & & 25,000 & 2,083 & 86 \\
\hline Fixed & Depreciation (Boats + Net + Lamps + Cables) & & 854,000 & 71,167 & 2,965 \\
\hline Wages of fishers & $\begin{array}{l}15000 \text { Frw } \times 12 \text { months }=180,000 \\
8000 \text { Frw } \times 8 \text { persons } \times 12 \text { months }=768000\end{array}$ & & 948,000 & 79,000 & 3,292 \\
\hline \multicolumn{2}{|l|}{ Insurance } & & 45,000 & 3,750 & 156 \\
\hline \multicolumn{2}{|c|}{ Maintenance cost of materials } & & 200,000 & 16,667 & 694 \\
\hline \multicolumn{2}{|l|}{ Total } & & & & 13,978 \\
\hline
\end{tabular}

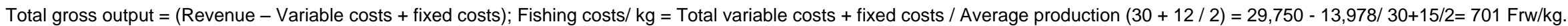

Oreochromis niloticus and Haplochromis sp. fishers. No wonder, $>62 \%$ of the Sardine fishers in this study were unaware of the law, though limited training is not the only impetus to poaching on the fisheries (Mugisha, 2020).

Government of Rwanda reported that on all the lakes in the country, apart from those within national parks, fishing malpractices were rampant for a long time (MINAGRI, 2011; Mugisha, 2020). Continuous use of illegal gears that is unregulated will eventually lead to the collapse of the fisheries sector in Rwanda. Indeed, overfishing, illegal and unregulated fishing and stock depletion are key issues threatening fishing activities around the world (Thomson, 2020; CFFA, 2020). Unless the growing trend of fishing malpractices especially the use of under-size mesh nets and increased fishing pressure are halted, collapse of the fisheries sector is eminent (Bennett et al., 2020). In contrast, adherence to regulation and compliance would boost sardine yields as such efforts have yielded results elsewhere (Singini et al., 2012). Retraining different actors and supporters should be done in a participatory and action-oriented way for all stakeholders especially members of Fishing Cooperatives and not just a few Cooperative leaders.

Also for better results, fishers should be trained from their own localities instead of being invited to townships away from their trade.

To streamline the TS fish value chain, it is vital for alliances between stakeholders to continue, particularly between KFP and the Fishing Union with the former continuing to supply fishing materials, ensure their quality control and affordability. In addition, the Fishing Union through a contract with KFP advocates and links fishers to microfinance institutions to access credit (RBS, 2020). Whereas fishers can access loans to capitalise fishing businesses, the amounts given should be increased and KFP should diversify the product portfolio to improve offer prices. Sardine fishers should supply fish on time, ensure hygiene and quality of inputs, and sort the fish supplied. The perishable nature of fish requires special attention on fish quality at end of the chain. To reach high value markets, the fish has to be of very good quality (FAO, 2020). When better quality is reached for instance by use of cold boxes to move fish, demand will increase and prices as well. Cold handling aligns with the new code of 
Table 3. Value shares of actors in the Tanganyika Sardine fish value.

\begin{tabular}{|c|c|c|c|c|c|c|}
\hline Actors & $\begin{array}{c}\text { Variable } \\
\text { cost }\end{array}$ & $\begin{array}{l}\text { Revenue } \\
\text { selling price }\end{array}$ & $\begin{array}{l}\text { Gross income } \\
\text { revenue - } \\
\text { costs }\end{array}$ & $\begin{array}{l}\text { Added value } \\
\text { revenue - previous } \\
\text { actor's revenue }\end{array}$ & $\begin{array}{c}\text { Gross margin } \\
\text { Gross income x } 100 \\
/ \text { Revenue }\end{array}$ & $\begin{array}{c}\text { Value shares } \\
\text { Added value } \times 100 / \\
\text { Retail price }\end{array}$ \\
\hline Fishermen & 701 & 1100 & 399 & 1100 & 36 & 59 \\
\hline Fishing Cooperatives and Union & 1150 & 1200 & 50 & 100 & 8 & 5 \\
\hline Kibuye Fishing Project & 1250 & 1450 & 200 & 250 & 17 & 14 \\
\hline Retailers & 1450 & 1850 & 400 & 400 & 5 & 22 \\
\hline Total & & & & & & 100 \\
\hline
\end{tabular}

Table 4. Historical diagram of Tanganyika Sardine fish value chain and fishing practices over 20 years in Karongi, Rutsiro and Nyamasheke districts.

\begin{tabular}{|c|c|c|c|c|c|}
\hline Parameter & 20 years ago & 15 years ago & 10 years ago & 5 years ago & 2020 \\
\hline \multicolumn{6}{|l|}{ Fish population } \\
\hline Limnothrissa miodon (Isambaza) & Were so many & Were many & Were many & Few & Few number \\
\hline $\begin{array}{l}\text { Lamrichthys tanganicus (Rwanda } \\
\text { rushya) }\end{array}$ & None & None & Few number & Number (decreased) & Many \\
\hline Haplochromis sp. & Were so many & Were many & Were many & Were many & Few number \\
\hline Oreochromis niloticus (Nile tilapia) & Were many & Were many & Were many & Were many & Few number \\
\hline Fishing practices (techniques) & $\begin{array}{l}\text { Were good fishing } \\
\text { practices }^{*}\end{array}$ & $\begin{array}{l}\text { Were good fishing } \\
\text { practices }\end{array}$ & $\begin{array}{l}\text { Started fishing } \\
\text { malpractices }\end{array}$ & $\begin{array}{l}\text { Increased fishing } \\
\text { malpractices }^{\star \star}\end{array}$ & $\begin{array}{l}\text { Ubiquitous fishing } \\
\text { malpractices }\end{array}$ \\
\hline $\begin{array}{l}\text { Awareness raising of fishing practices } \\
\text { and organisation focus on extension }\end{array}$ & None & $\begin{array}{l}\text { Started with } \\
\text { FAO/MINAGRI }\end{array}$ & $\begin{array}{l}\text { Increased with } \\
\text { MINAGRI }\end{array}$ & $\begin{array}{l}\text { Increased continuously with } \\
\text { RARDA, KFP \& PAIGELAC }\end{array}$ & $\begin{array}{l}\text { Increased enormously } \\
\text { with RABKFP }\end{array}$ \\
\hline Number of Fishing Unit (FU) & $\begin{array}{l}\text { They were too few } \\
2 \mathrm{FU}\end{array}$ & $\begin{array}{l}\text { Number increased } \\
6 \mathrm{FU}\end{array}$ & $\begin{array}{l}\text { Number increased } \\
15 \mathrm{FU}\end{array}$ & $\begin{array}{l}\text { Number increased } \\
20 \mathrm{FU}\end{array}$ & $\begin{array}{l}\text { Number increased } \\
36 \mathrm{FU}\end{array}$ \\
\hline Production/ fishing unit (kg/ day) & 300 & $100-150$ & $50-100$ & 50 & $10-30$ \\
\hline Cooperative & $\begin{array}{l}\text { None (fishers worked } \\
\text { individually) }\end{array}$ & $\begin{array}{l}\text { None (fishers } \\
\text { worked individually) }\end{array}$ & $\begin{array}{l}\text { Started with formation } \\
\text { of association }\end{array}$ & Had started & Available \\
\hline Quality standard of fish & None & Did not exist & Did not exist & Started with KFP & Available \\
\hline Prices (Frw/kg) & 20 & $30-50$ & $100-150$ & $600-800$ & $1000-1500$ \\
\hline Customers & None & Little number & Number increased & Increased further & So many \\
\hline Fishing license & Not required & Not required & Required & Required & Required \\
\hline Extension institutions and supporters & None & FAO project & FAO project & $\begin{array}{l}\text { Canadian Cooperation, } \\
\text { PAIGELAC, RARDA }\end{array}$ & $\begin{array}{l}\text { RAB, RBS } \\
\text { RCA District }\end{array}$ \\
\hline
\end{tabular}

* Good fishing practices: Using three filaments net, size: $5 \mathrm{~mm} \times 5 \mathrm{~mm}$ and Trimaran boat (fishing unit); ${ }^{*}$ Fishing malpractices: Using monofilament net (called Kaningini net), supernet, size: $4 \mathrm{~mm} \times$ $4 \mathrm{~mm}$ and below.PAIGELAC: Inland Lakes Integrated Development and Management Support. 
Table 5. SWOT analysis for the Tanganyika Sardine fish value chain in Karongi, Rutsiro and Nyamasheke districts.

\section{Strengths}

(i) Source of finance to the fisheries sector in the district available;

(ii) Strong institutional organization (RAB) works closely in training of fishers in extension fishing techniques;

(iii) Potential of engaging gender in fish trading;

(iv) Good relationship and information sharing among most of actors of supply chain;

\section{Opportunities}

(i) Increasing demand for fish;

(ii) Available market for the fishing products;

(iii) Processing to add value to Tanganyika Sardine products

(iv) Existing law determining the organization and management of aquaculture and fishing in Rwanda;

(v) Water resource available in the district;

(vi) Preference by customers for fresh Tanganyika Sardine and products;

(vii) Fish sector is in priority list of government for strategic support

\section{Weaknesses}

(i) Overfishing;

(ii) Fishing malpractices;

(iii) Using destructive gears;

(iv) Inadequate management of Lake Kivu;

(v) Insufficiency of equipment in the sector;

(vi) Lack of implementation of government policy, rules and regulations for fish quality control of the chain.

(vii) Fishing without fishing license.

(viii) Fishing gears which are not insured

\section{Threats}

(i) Drowning of fishers due to wind or waves

(ii) High cost of materials especially nets resulting in high cost of fishing practice for handling, processing and distribution of fish (RBS, 2020). More training on fish quality is needed from KFP as the lead actor and supporters RAB and RBS to ensure high-quality handling of fish (FAO, 2012).

\section{Costs, benefits and value shares of actors in the fish value chain}

Considering that fishermen receive only $59 \%$ of the retail price of their fish, and yet the average fishing cost is $37.9 \%$ of the retail price, the 399 $\mathrm{Frw} / \mathrm{kg}$ offered (Table 2) is not enough as a price differential. Indeed, projection of daily earnings amount to an average of 85,000 Frw/year, a revenue that is so low that keeping in business is a challenge. Additionally, fishing malpractices arising mainly due to the lack of knowledge and organization and responsible for $30 \%$ of the fish on the market should be tackled. The likely implication of continuous decrease in fish catches as shown in the historical diagram (Table 3) will be extreme demand for the fish that will no longer reach the plate. An assessment of the likely scenarios resulting from severe declines in average catches of fish in Tanzania (Cinner et al., 2011) found that fishers use amplifying adaptations such as fishing harder, than dampening adaptations such as reducing effort. Sharing of information among actors and supporters should be promoted to increase coordination and trust and this will be the best way to improve Tanganyika Sardine fish value chain.

Value chain analysis describes the full range of activities which are required to bring a product or service from conception, through the various phases of production that may involve a combination of physical transformation and the input of various producer services to final consumers and final disposal after use (Nicolae et al., 2017); and this was one of the foci of this research endeavour. The low awareness of the law determining the organisation and management of the fishing in Rwanda and the lack of good coordination in surveillance of fishing practices were vivid and appear to be the origin of the 
value chain is well structured compared to other agricultural enterprises; it has a host of passionate stakeholders and can go a long way to transform the fishing sector in Rwanda. However, serious efforts must be put on increasing the productivity of the lake because the lake cannot support the fish demand in the country and other avenues such as aquaculture should be upscaled quickly.

\section{CONFLICT OF INTERESTS}

The authors have not declared any conflict of interests.

\section{ACKNOWLEDGEMENTS}

The authors gratefully thank the Fishing Cooperatives, Fishing Union management, Retailer Cooperatives, Kibuye Fishing Project, Marine Rwanda National Police, Karongi Rutsiro and Nyamasheke districts leaders that participated in the study. We are also very grateful to the several anonymous reviewers whose insightful comments greatly improved the manuscript. This work was part of an MSc thesis of the first author.

\section{REFERENCES}

Aura CM, Nyamweya CS, Odoli CO, Owiti H, Njiru JM, Otuo PW, Waithaka E, Malala J (2020). Consequences of calamities and their management: The case of COVID-19 pandemic and flooding on inland capture fisheries in Kenya. Journal of Great Lakes Research 46:1767-1775.

Belton B, van Asseldonk IJM, Thilsted SH (2014). Faultering fisheries and ascendant aquaculture: Implications for food and nutrition security in Bangladesh. Food Policy 44:77-87.

Bennett A, Patil P, Kleisner K, Rader D, Virdin J, Basurto X (2018). Contribution of fisheries to food and nutrition security:Current knowledge, policy, and research. NI Report 18-02. Durham, NC: Duke University.

Bennett NJ, Finkbeiner EM, Ban NC, Belhabib D, Jupiter SD, Kittinger JN, Mangubhai S, Scholtens J, Gill D, Christie P (2020). The COVID19 pandemic, small-scale fisheries and coastal fishing communities. Coastal Management 48(4):336-347.

Bjorndal T, Child A, Lem A (eds) (2010). Value Chain Analysis Template. Rome: FAO NORAD Project.

Cinner JE (2009). Poverty and the use of destructive fishing gear near east African marine protected areas. Environnemental Conservation 36(4):321-326.

Cinner JE, Folke C, Daw T, Hicks CC (2011). Responding to change: using scenarios to understand how socioeconomic factors may influence amplifying or dampening exploitation feedbacks among Tanzanian fishers. Global Environmental Change 21(1):7-12.

Coalition for Fair Fisheries Agreements (CFFA) (2020). Reducing control during the Covid-19 outbreak would open the door to illegal fishing. Coalition for Fair Fisheries Agreements. April 16, 2020.

Cowx IG, Ogutu-Owhayo R (2019). Towards sustainable fisheries and aquaculture management in the African Great Lakes. Fisheries Management and Ecology 26(5):397-405.

Duan H, Wang S, Yang C (2020). Coronavirus: limit short-term economic damage. Nature 578(7796):515

Food and Agriculture Organization of the United Nations (FAO) (2012). Code of Practice for fish and fishery products. Wold Health Organisation. Food and Agriculture Organisation of the United Nations. FAO. Rome. Italy.
Food and Agriculture Organization of the United Nations (FAO) (2018a). The State of World Fisheries and Aquaculture 2018-Meeting the Sustainable Development Goals; FAO: Rome, Italy.

Food and Agriculture Organization of the United Nations (FAO) (2020). Food Loss and Waste in Fish Value Chains, Accessed on August 2020 from: www.fao.org/flw-in-fish-value-chains/solutions/markets/en/

Funge-Smith S, Bennett A (2019). A fresh look at inland fisheries and their role in food security and livelihoods. Fish and Fisheries 20:11761195.

Giannakis E, Hadjioannou L, Jimenez C, Papageorgiou M, Karonias A, Petrou A (2020). Economic consequences of Coronavirus Disease (COVID-19) on fisheries in the Eastern Mediterranean (Cyprus). Sustainability 12:9406; doi:10.3390/su12229406.

Guillard J, Darchambeau F, Masilya P, Mulungula CD, Descy JP (2012). Is the fishery of the introduced Tanganyika sardine (Limnothrissa miodon) in Lake Kivu (East Africa) sustainable? Journal of Great Lakes Research 38:524-533.

Hall SJ, Hilborn R, Andrew NL, Allison EH (2013). Innovations in capture fisheries are an imperative for nutrition security in the developing world. Proceedings of the National Academy of Sciences of United States of America 110(21):8393-8398.

Hanazaki N, Begossi A (2010). Does fish still matter? Changes in the diet of two Brazilian fishing communities. Ecology of Food and Nutrition 42(4-5):279-301.

Harper S, Zeller D, Hauzer M, Pauly D, Sumaila UR (2013). Women and fisheries: Contribution to food security and local economies. Marine Policy 39:56-63.

Hicks CC, Cohen PJ, Graham NAJ, Nash KL, Allison EH, D'Lima C, Mills DJ, Roscher M, Thilsted SH, Thorne-Lyman AL, MacNeil MA (2019). Harnessing global fisheries to tackle micronutrient deficiencies. Nature 574:95-98.

Israel GD (1992). Sampling the Evidence of Extension Program Impact. Program Evaluation and Organizational Development. University of Florida, PEOD-5.

lyiola AO, Asiedu B, Fawole FJ (2020). Possible effects of COVID-19 on sustainability of aquatic ecosystems: An overview. Aquatic Research 3(4):177-187

Junker J, Rick JA, McIntyre PB, Kimirei I, Sweke EA, Mosille JB, Wehrli B, Dinkel C, Mwaiko S, Seehausen O, Wagner CE (2020). Structural genomic variation leads to genetic differentiation in Lake Tanganyika's sardines. Molecular Ecology 29(17):3277-3298, https://doi.org/10.1111/mec.15559.

Kaewnuratchadasorn P, Smithrithee M, Sato A, Wanchana W, Tongdee $\mathrm{N}$, Sulit T (2020). Capturing the impacts of COVID-19 on the fisheries value chain of Southeast Asia. Southeast Asian Fisheries Development Center, Fish for the People 18(2):1-8.

Khan N, Siddiqui BN, Khan N, Ullah N, Wali A, Khan IU, Ismail S, Ihtisham M (2021). Drastic impacts of COVID-19 on food, agriculture and economy. Pure and Applied Biology 10(1):62-68. http://dx.doi.org/10.19045/bspab.2021.100008

Kibuye Fisheries Project (KFP) (2020). Communication on recent developments on the fisheries sector for Lake Kivu by the Coordinator, December 2020.

Kisekelwa T, Snoeks J, Vreven E (2020). An annotated checklist of the fish fauna of the river systems draining the Kahuzi-Biega National Park (Upper Congo: Eastern DR Congo). Journal of Fish Biology 96(3):700-721.

Kolding J, van Zwieten P, Marttin F, Funge-Smith S, Poulain F (2019). Freshwater small pelagic fish and fisheries in major African lakes and reservoirs in relation to food security and nutrition. FAO Fisheries and Aquaculture Technical Paper No. 642. Rome, FAO. P 124.

MINAGRI (Ministry of Agriculture and Animal Resources) (2011). Master plan for the fisheries and fish farming in Rwanda, MINAGRI. Kigali. Rwanda.

Mugisha EC (2020). Rwanda: Government commits to uproot illegal fishing practices. The New Times (Kigali), published January 26, 2020; https://allafrica.com/stories/202001270078.html.

Muzana A, Guillard J (2014). Stock estimation of Limnothrissa miodon in Lake Kivu: assessment of seasonal and spatial variation of fish

abundance. A report of the Biological baseline study of Lake Kivu, Belgian Development Cooperation, REG/CARRTEL 34 p.

Nibeza S (2015). Sustainable environment, a key of sustainable 
development - A case study of Rwanda. International Journal of Research in Economics and Social Sciences 5(6):20-36.

Nicolae CG, Moga LM, Bahaciu GV, Marin MP (2020). Traceability system structure design for fish and fish products based on supply chain actor's needs. Scientific Papers Series D. Animal Science 60:353-358.

Obiero K, Meulenbroek P, Drexler S, Dagne A, Akoll P, Odong R, Kaunda-Arara B, Waidbacher H (2019). The contribution of fish to food and nutrition security in Eastern Africa: Emerging trends and future outlooks. Sustainability 11:1636.

Rwanda Bureau of Standards (RBS) (2020). Handling, processing and distribution of fish, code of practice. Available at: https://www.rsb.gov.rw/

Rwanda Utilities Regulatory Authority (RURA) (2016). Contribution of regulated sectors to the GDP: Year ended 2015. RURA. Kigali. Rwanda.

Singini W, Kaunda E, Kasulo V, Jere W (2012). Modelling and forecasting small haplochromine species (Kambuzi) production in Malawi - A stochastic model approach. International Journal of Scientific and Technology Research 1:69-73.

Smith SL, Golden A, Ramenzoni V, Zemeckis DR, Jensen OP (2020). Adaptation and resilience of commercial fishers in the Northeastern United States during the early stages of the COVID-19 pandemic. SocArXiv Papers. https://doi.org/10.31235/osf.io/z3v2h.

Snoeks J, Kaningini B, Masilya P, Nyina-Wamwiza L, Guillard J (2012). Fishes in Lake Kivu: Diversity and fisheries. In: Descy JP, Darchambeau $F$ and Schmid M (eds.) Lake Kivu: Limnology and biogeochemistry of a tropical great lake. Aquatic Ecology Series 5:127-152.

Spliethoff P, Murasira P (2013). Quick scan to identify and discuss options for improved fish production in Rwanda. Project Report Report number CDI-13-017, Centre for Development Innovation. Wageningen UR.
Stokes GL, Lynch AJ, Lowe BS, Funge-Smith S, Valbo-Jørgensen J, Smidt SJ (2020). COVID-19 pandemic impacts on global inland fisheries. Proceedings of the National Academy of Sciences of the USA 117(47):29419-29421.

Teh L, Teh L (2016). Malaysia, in Global Atlas of Marine Fisheries: A Critical Appraisal of Catches and Ecosystem Impacts, eds D. Pauly and D. Zeller (Washington, DC: Island Press) pp. 323-325.

Teh LC, Pauly D (2018). Who brings in the fish? The relative contribution of small-scale and industrial fisheries to food security in Southeast Asia. Frontiers in Marine Science 5(44):9. doi: 10.3389/fmars.2018.00044.

Thomson J (2020). Fisheries and oceans Canada pulls at-sea observers from fishing boats due to coronavirus pandemic. The Narwhal, April 8, 2020. https://thenarwhal.ca/fisheries-oceanscanada-pulls-at-sea-observers-fishing-boats-coronavirus-covid-19/.

United Nations (2020a). Leaving None Behind - From the COVID-19 response to recovery and resilience building: Analyses of the socioeconomic impact of COVID-19 in Uganda. United Nations in Uganda P 174.

United Nations (2020b). The socio-economic impact of COVID-19 in Rwanda, COVID-19 Response. United Nations in Rwanda, 129 pp.

Webber CM, Labaste P (2010). Building competitiveness in Africa's agriculture: a guide to value chain concepts and applications. Agriculture and rural development Series, The World Bank, Washington DC $187 \mathrm{p}$.

Zhang S, Wang S, Yuan L (2020). The impact of epidemics on agricultural production and forecast of COVID-19. China Agricultural Economic Review 12(3):409-425. doi: 10.1108/caer-04-2020-0055. 